\title{
SOCIJALNA PODUZEĆA ZA RADNU INTEGRACIJU (WISE) U POSTSOCIJALISTIČKIM ZEMLJAMA
}

\author{
LUKA MARKOVIĆ, DANIJEL BATURINA, ZDENKO BABIĆ
}

Pravni fakultet Zagreb, kontakt: danijel.baturina@pravo.hr

Primljeno: 21.11.2016.

Pregledni rad

Prihvaćeno: 8.5.2017.

UDK: $658: 364$

Sažetak: Socijalna država stoji pred zahtjevima modernizacije u pogledu brige za svoje najranjivije skupine. Osobe s invaliditetom su u posebno ugroženom položaju s brojnim preprekama za pristup tržištu rada. Značajan prostor za njihovu integraciju se vidi o području socijalnih poduzeća. Karakteristike i uloge socijalnog poduzetništtva, a posebice socijalnih poduzeća za radnu integraciju (WISE) su obrazložene u početnim dijelovima rada. Analiza je provođena u okviru postsocijalističkih EU zemalja- Poljske, Slovenije, Slovačke, Češke i Hrvatske. Utvrdili smo nekoliko općih karakteristika bitnih za razvoj socijalnih poduzeća za radnu integraciju, primjerice postojanje pojedinih oblika financiranja, određenog zakonodavno- institucionalnog okvira koji su ipak nedostatni. Pitanja poput nedostatne promocije, osvještavanja i neadekvatnih vještina utječu da socijalna poduzeća za radnu integraciju u postsocijalističkim europskim državama karakterizira zakašnjeli razvoj. U Hrvatskoj je to posebno istaknuto. Socijalna poduzeća za radnu integraciju u Hrvatskoj još uvijek tendiraju biti malobrojna i zapošljavati malen broj zaposlenika. Rad daje i preporuke za unapređenje položaja socijalnih poduzeća za radnu integraciju u Hrvatskoj kako bi se unaprijedile njihove mogućnosti u zapošljavanju i socijalnom uključivanju osoba sa invaliditetom i drugih ranjivih skupina.

Ključne riječi: socijalno poduzetništvo, socijalna poduzeća za radnu integraciju, osobe sa invaliditetom, zapošljavanje i socijalno uključivanje.

\section{UVOD}

Posljednjih desetljeća ističe se važnost socijalnog poduzetništva u društvu. Faktori koji su djelovali sa strane potražnje bile su ekološke krize i krize u zdravstvu, povećana ekonomska nejednakost, neučinkovitost država u pružanju javnih usluga, povlačenje država u susretu s ideologijom slobodnog tržišta, povećana uloga civilnog društva te natjecanje za resurse (Nicholls, 2006.:2). Osim toga, javlja se strukturna nezaposlenost među određenim skupinama, te poteškoće tradicionalnih aktivnih politika tržišta rada da uspješno integriraju pojedine skupine na tržište rada.

Socijalno poduzetništvo nije više na marginama društva, nego se pojavljuje kao nezavisno polje istraživanja potaknuto brojnim pozitivnim primjerima iz prakse kao i većim prepoznavanjem $\mathrm{s}$ institucionalne razine. Socijalno poduzetničkim pothvatima glavna je svrha stvoriti pozitivan društveni utjecaj. Ključna razlika između poduzetništva u poslovnom sektoru i socijalnog poduzetništva jest $u$ relativnom prioritetu za stvaranje dobrobiti i postizanja socijalnih ciljeva (Austin, i sur., 2006; Peredo i McLean, 2006). No, ono je dobrim dijelom orijentirano na pružanje socijalnih usluga $i$ socijalno uključivanje marginaliziranih skupina na tržište rada i u društvo.

Danas je perspektiva socijalne države uvelike određena perspektivom socijalnih rizika, posebice novih socijalnih rizika. Socijalna država stoji pred zahtjevima modernizacije u pogledu brige za svoje najranjivije skupine. Osobe s invaliditetom u posebno su ugroženom položaju, s višestrukim preprekama, od kojih se mnoge odnose na pristup tržištu rada. Značajan prostor za njihovu integraciju vidi se u području trećeg sektora, a u novije vrijeme naglašeno i socijalnih poduzeća. Kao što će biti vidljivo iz daljnje analize, 60-tih i 70-tih godina 20. stoljeća svjedočimo promjeni paradigme o ulozi socijalnih poduzeća kao pokretača zajednice: socijalna poduzeća više se ne vide samo kao akteri koji proizvode određeni proizvod ili uslugu za zajednicu, nego i kao akteri koji promoviraju jednu dodatnu vrstu društvene vrijednosti - integraciju 
odnosno inkluziju ranjivih skupina u društvo putem zapošljavanja. Započinje nova era promišljanja kako razvijati socijalna poduzeća za radnu integraciju (Work Integration Social Enterprise- WISE) kao aktera koji doprinose zapošljavanju osoba s otežanim pristupom tržištu rada.

Ovaj rad stoga ima za temeljni cilj istražiti koja su glavna obilježja razvoja socijalnih poduzeća za radnu integraciju (WISE) u postsocijalističkim europskim zemljama. Rad će se najprije kratko osvrnuti na karakteristike i ulogu socijalnog poduzetništva u društvu, dok će se u drugom poglavlju razmatrati koncept, uloga i vrste WISE socijalnih poduzeća za radnu integraciju. Dalje će se raspraviti o socijalnim poduzećima za radnu integraciju u postsocijalističkim europskim zemljama analizirajući njihov razvoj i mogućnosti. Kratko ćemo sagledati razvoj socijalnog poduzetništva u Hrvatskoj. Nadalje, posebno ćemo se osvrnuti na trenutno stanje i mogućnosti radne i društvene integracije osoba s invaliditetom u Hrvatskoj. U raspravi će se predstaviti zaključci komparativne analize, utvrđujući koje su sličnosti i razlike između promatranih zemalja i potencijali za razvoj. Zaključak će se osvrnuti na preduvjete za razvoj socijalnog poduzetništva za radnu integraciju u Hrvatskoj, donijeti sukus lekcija naučenih iz komparativne analize, te preporuke za daljnje mogućnosti radne integracije osoba $\mathrm{s}$ invaliditetom i njihove perspektive u ovom tipu socijalnog poduzetništva u Hrvatskoj.

\section{SOCIJALNO PODUZETNIŠTVO - ODREDNICE}

Socijalno poduzetništvo pokazuje se kao značajan čimbenik u ostvarivanju pozitivnih promjena $\mathrm{u}$ društvu. Brojne su definicije ${ }^{1}$ socijalnog poduzetništva. Primjerice, socijalno poduzetništvo jest kada je neka osoba ili grupa usmjerena k stvaranju socijalne vrijednosti, pokazuje kapacitet da prepozna i iskoristi prilike, upošljava inovacije, prihvaća iznadprosječnu količinu ekonomskog rizika u slijeđenju svoje socijalne misije (Paredo i McLean, 2006). Socijalna se poduzeća razlikuju od tradicionalnih poduzeća, kako to opisuju Boschee i McClurg, (2003.:3). To razlikovanje proizlazi iz različitog određenja uspjeha poduzeća. Dok socijalna poduzeća strategije stvaranje prihoda usmjeravaju ostvarivanju socijalne misije, tradicionalna poduzeća ih usmjeravaju ka generiranju profita za vlasnike. Za socijalna poduzeća kažemo da imaju dvostruku liniju sagledavanja uspjeha. Ona teže ostvariti profit, no taj se profit u cijelosti ili najvećoj mjeri reinvestira u socijalnu misiju, te je dalje osnažuje i podupire (Nicholls, 2006.:11-12).

Možemo govoriti o dva aspekta koji socijalno poduzetništvo čine adekvatnim instrumentom u ostvarivanju te pozitivne promjene. Prvi je aspekt - socijalni aspekt, koji naglašava trajnu usmjerenost socijalnog poduzetništva pomaganju obespravljenih i ranjivih skupina u društvu. Većina teoretičara socijalno poduzetništvo vidi kao djelatnost koja je usmjerena ostvarivanju socijalne misije (Robinson, 2006; Hockerts, 2006; Desa i Kotha, 2006; Haugh, 2006), rješavanju socijalnih problema (Robinson, 2006, Seelos i sur., 2006) te zadovoljavanju socijalnih potreba (Desa i Kotha, 2006; Haugh, 2006). Primarnost socijalne misije ključni je element koji odvaja socijalna od tradicionalnih poduzeća. Tako je uloga socijalnog poduzetništva da utvrdi socijalne probleme i potrebe s kojima se određena ranjiva i marginalizirana skupina u društvu susreće, na temelju kojih socijalna poduzeća poduzimaju napore kojima će osigurati rješavanje tih problema i zadovoljavanje tih potreba.

Ekonomski aspekt socijalnog poduzetništva ističe ekonomske procese kao bitne faktore u postizanju pozitivnih društvenih promjena. Velik dio teoretičara naglašavaju održivost i uspješno poslovanje (Robinson, 200; Desa i Kotha, 2006) te proizvodnju dobara i usluga (Seelos i sur., 2006; Haugh, 2006) kao važne elemente pri definiranju socijalnog poduzetništva. Naime, socijalna poduzeća moraju rješavati socijalne probleme na održiv način - proizvodnjom i prodajom dobara i usluga kojima generiraju profit, i tako osiguravaju svoj opstanak na tržištu. Naglasak se tako stavlja na proizvodnju socijalnih usluga na trajnoj osnovi u djelatnostima gdje nije moguće razviti gospodarsko-tržišnu djelatnost (Bežovan, 2008). Poduzetnička dimenzija podrazumijeva uključenost u kontinuiranu ekonomsku aktivnost, prepoznava-

1 Više o različitim načinima definiranja u Baturina, 2013. 
nje i iskorištavanje prilika te preuzimanje rizika. Oni se moraju oslanjati na poslovne mehanizme i barem djelomično na tržište.

Izdvaja se nekoliko škola socijalnog poduzetništva. Autori Defourny i Nyssens (2010, 2012) sagledavaju socijalno poduzetništvo kroz škole misli koje ga oblikuju. Jedna od njih² i je EMES ${ }^{3}-$ ov pristup koji se profilirao u europskoj istraživačkoj zajednici. On je ideal tipski u Webber-ovom smislu, dakle predstavlja apstraktnu konstrukciju koja omogućuje istraživačima da se pozicioniraju unutar "galaksije" socijalnih poduzeća (Defourny i Nyssens, 2012). Prema tom usmjerenju, Defourny (2001.:6-8) navodi kriterije ${ }^{4}$ za socijalna poduzeća koji se odnose na socijalnu i ekonomsku dimenziju, ali za razliku od drugih koncepcija naglašavaju participatornu narav socijalnog poduzetništva.

Iako postoji i američka koncepcija ${ }^{5}$, za naša poimanja uvelike je značajnija kontinentalno-europska koncepcija socijalnog poduzetništva. U zapadnoj Europi institucionalna je potpora uglavnom vezana za vlade i Europsku uniju. Razvile su se razne sheme javnih potpora (više u Baturina, 2013). Na razini Europske Unije isticale su se inicijative poput Single Market Act ${ }^{6}$, inicijative Inovation Union ${ }^{7}$, Social Business Initiative 8 te zaključka komisije The promotion of the social economy as a key driver of economic and social te development in Europe, koji jednoznačno i argumentirano podržava razvoj socijalne ekonomije i poduzetništva. Europska unija vidi socijalno poduzetništvo kao poslovni model koji može istovremeno rješavati pitanja ekonomskog rasta, zaposlenosti i kvalitete života (Defourny i Nyssens, 201;, Kerlin, 2006). U Europi postoji povijesna tradicija povezivanja socijalnog poduzetništva s pitanjima demokracije i participacije te je povezana s evolucijom socijalne politike. Iz razmatranja socijalne politike javile su se i inicijative zapošljavanja ranjivih i marginaliziranih skupina $u$ socijalnim poduzećima za radnu integraciju, kako bi se doprinijelo proizvodnji tih socijalnih proizvoda i usluga, a u svrhu uključivanja u svijet rada $i$ integracije u zajednicu ovih skupina.

Socijalno se poduzetništvo u drugoj polovici 20. stoljeća značajno razvija u zapadnoj Europi, što se ne može reći i za istočne i jugoistočne postsocijalističke europske zemlje. Glavni razlog usporenog razvoja socijalnog poduzetništva u tim zemljama pripisuje se zakašnjelom razvoju civilnog i volonterskog sektora. Zbog represivne prirode socijalističkih režima u Europi, civilni sektor i organizacije civilnog društva bili su marginalizirani i potpuno kontrolirani od strane komunističke partije, pri čemu udruge i zadruge postaju produžetak države i igraju ulogu kvazi-vladinih agencija (Bežovan i Zrinščak 2007; Ciepielewska-Kowalik i sur. 2015). U post-komunističkoj Europi do porasta aktivnosti socijalnih poduzeća dolazi tek krajem 80-tih i početkom 90-tih godina, i to poglavito zbog demokratizacije društva, decentralizacije i transformacije socijalne države u tim zemljama (Ciepielewska-Kowalik i sur., 2015). Socijalna poduzeća za radnu integraciju isto se tako razvijaju sa zakašnjenjem, iako postoje određene tradicije njima srodnih oblika. O karakteristikama socijalnih poduzeća za radnu integraciju više ćemo reći u sljedećem odjeljku.

2 Ostala dva su (Defourny i Nyssens, 2010): ,zarađivanje prihoda“ (eng. earned income). On se fokusira na strategije zarađivanja prihoda i tržišne aktivnosti neprofitnih organizacija koje su u službi podupiranja njihove misije. „Socijalne inovacije“ su druga škola misli, u kojoj su glavni čimbenici promjene, tj. nove kombinacije koje se razvijaju i agenti koji proizvode te promjene.

3 EMES je istraživačka mreža etabliranih sveučilišnih istraživačkih centara i pojedinih istraživača koja ih okuplja oko područja socijalnog poduzetništva, što je rezultiralo brojnim tekstovima i publikacijama na tu temu.

4 Prva četiri odnose se na ekonomsku dimenziju. 1. Uključenost u kontinuirane aktivnosti proizvodnje dobara i/ili njihove prodaje. 2. Visoka razina autonomije: oni su dobrovoljno osnovani od strane grupe ljudi i upravljani od njih. 3. Značajan nivo ekonomskog rizika. Njihova ekonomska održivost ovisi o naporima njihovih članova da osiguraju adekvatne resurse. 4. Minimalna razina plaćenog rada. Daljnjih pet kriterija utjelovljuje socijalne dimenzije inicijative. 5. Specifična usmjerenost na dobrobit zajednice. Njihov glavni cilj je služiti zajednici ili specifičnoj grupi ljudi. 6. Inicijativa je pokrenuta od strane grupe građana. Ona je rezultat kolektivne dinamike koja uključuje ljude koji pripadaju zajednici ili grupe koja dijeli iste vrijednosti. 7. Moć pri donošenju odluka nije bazirana na vlasništvu kapitala. To općenito znači da se koristi princip ,jedan član, jedan glas“, ili barem glasačka moć nije distribuirana prema udjelu kapitala. 8. Participatorna narav, koja uključuje osobe na koje se odnosi aktivnost. Reprezentacija i participacija korisnika je uključena, orijentacija je prema dionicima i postoji demokratski stil menadžmenta. 9. Limitirana distribucija prihoda. Organizacije ne distribuiraju prihod, ili ga u manjoj mjeri distribuiraju među svojim članovima.

5 Više o američkoj koncepciji socijalnog poduzetništva u Baturina, 2013.

$6 \mathrm{http}: / /$ ec.europa.eu/internal market/smact/docs/20120206 new growth en.pdf

$7 \mathrm{http} / / /$ ec.europa.eu/internal_market/smact/docs/20120206_new_growth_en.pdf

8 http://ec.europa.eu/internal market/social business/docs/COM2011 $68 \overline{2}$ en.pdf

9 http://data.consilium.europa.eu/doc/document/ST-13766-2015-INIT/en/pdf 


\section{SOCIJALNA PODUZEĆA ZA RADNU INTEGRACIJU}

Europske države od sredine 20. stoljeća počinju značajnije poticati razvoj i djelovanje socijalnog poduzetništva i socijalnih poduzeća za radnu integraciju. Prve inicijative socijalnih poduzeća za radnu integraciju pokrenute su na prijelazu iz $1970-\mathrm{ih}^{10}$, bez bilo kakvih javnih potpora. Većinu "pionirskih" socijalnih poduzeća za radnu integraciju osnovali su akteri civilnog društva: socijalni radnici, aktivisti zajednice, sindikata, i drugi potaknuti kontekstom nezaposlenosti. Od 80-tih inicijative socijalnih poduzeća za radnu integraciju bivaju prepoznatije među dionicima politika u procesu razvoja aktivnih politika tržišta rada, te se dijelom vide kao alat implementacije ovih politika (Nyssens, i sur., 2012). Isti autori naglašavaju da su socijalna poduzeća za radnu integraciju prepoznata na tri značajna načina: 1) kao legalni oblik, 2) kroz specifične javne sheme potpora i 3) u davanju pristupa aktivnih politika zapošljavanja kao i bilo kojim drugim poduzećima.

Socijalna poduzeća za radnu integraciju prepoznaje se kao jedan od glavnih tipova socijalnih poduzeća (Defourny i Nyssens 2012; Spear i Bidet, 2003). ${ }^{11}$ Socijalna poduzeća za radnu integraciju značajno doprinose integraciji osoba s invaliditetom u društvo. Njihova osnovna svrha leži u pomaganju pojedincima koji su u riziku od trajne socijalne isključenosti s tržišta rada da se integriraju u svijet rada i u društvo, putem produktivnih aktivnosti odnosno putem njihova zapošljavanja (Defourny i Nyssens, 2008; Spear i Bidet, 2003). Socijalna poduzeća za radnu integraciju integriraju osobe s invaliditetom u društvo pružajući im niz usluga: treninga, socijalne podrške i zaposlenja, kojima se osobama s invaliditetom nastoji osigurati razvoj radnih vještina i kompetencija, radnih navika i ekonomske samostalnosti (Defourny i Nyssens 2008; Davister i sur., 2004). Socijalna poduzeća za radnu integraciju osoba s invaliditetom, kako navo- de Spear i Bidet (2003), pojavila su se prije drugih tipova socijalnih poduzeća za radnu integraciju, te do danas ostaju jedno od glavnih usmjerenja tih tipova inicijativa.

Sveobuhvatno istraživanje socijalnih poduzeća za radnu integraciju u EU u ranim 2000-tima procjenjuje da je ih je bilo više od 14.209 , te su u to vrijeme zapošljavala 239.977 ljudi (Spear i Bidet, 2003). Prema recentnijem istraživanju u manjem uzorku EU zemalja, gotovo 15\% socijalnih poduzeća EU-a smatraju se socijalnim poduzećima za radnu integraciju, s misijom zaposliti i obučiti radnike u vrlo nepovoljnom položaju na tržištu rada (SELUSI ${ }^{12}$ u European Commision, 2013). No socijalna poduzeća za radnu integraciju u EU često su manjeg opsega i djelovanje im je više usmjereno na lokalne razine (Heckl i sur., 2007; DIESIS 2009; Defourny i Nyssens 2008).

Dakle, socijalna poduzeća za radnu integraciju integriraju radnike s invaliditetom na tržište rada. Oni imaju određene prednosti naspram njihovog zapošljavanja na otvorenom tržištu rada. Kao barijere na otvorenom tržištu rada, primjerice u hrvatskom kontekstu, navode se stigmatizacija od strane poslodavaca (Skočić Mihić, 2004), troškovi prilagodbe radnog mjesta potrebama osoba s invaliditetom (Kiš-Glavaš i Sokač, 2006), neadekvatnost kvotnog sustava u poticanju zapošljavanja osoba s invaliditetom (Fuchs, 2014), te slaba educiranost i nedovoljna usklađenost znanja i vještina s potrebama otvorenog tržišta rada. Socijalna poduzeća za radnu integraciju načelno nemaju predrasuda prema osobama s invaliditetom i ne stigmatiziraju ih prilikom zapošljavanja; prilikom osnivanja brinu da radna mjesta budu prilagođena njihovim potrebama i mogućnostima.

Socijalna poduzeća za radnu integraciju možemo tipizirati na različite načine. Davister i sur. (2004) napravili su najkonzistentniju tipologiju sagledavanja ove vrste socijalnih poduzeća. Oni razlikuju socijalna poduzeća za radnu integraciju i)

10 Iako inicijative u nekom oblicima i skromnijeg dosega kreću i ranije. Švicarska 50-tih godina 20.st. uvodi osiguranje u slučaju invalidnosti te obvezuje kantonalne vlasti da financiraju rad WISE na svojem području (Adam i sur., 2015); u Belgiji se već 60-tih godina otvaraju prva WISE za osobe s invaliditetom, a 70-tih organizacije civilnog društva pokreću brojne inicijative kako bi unaprijedile zapošljavanje ranjivih skupina putem WISE (dugotrajno nezaposleni, osobe s malo radnog iskustva i osobe s razvijenim socijalnim problemima) (Huybrechts i sur., 2016). Nadalje, WISE za zapošljavanje osoba s invaliditetom počinju djelovati i u ostalim europskim državama - ona se otvaraju u Njemačkoj 60-tih (Birkhölzer i sur., 2015), u Francuskoj 70-tih (Fraisse i sur., 2016), a u Španjolskoj 80-tih godina 20.st (Vidal i Claver, 2004).

11 Iako se sama socijalna poduzeća za radnu integraciju razlikuju u različitim socio-ekonomskim i zakonodavnim kontekstima. Nyssens (2014) navodi da se više od 50 različitih varijacija inicijativa socijalnih poduzeća za radnu integraciju pojavilo u Europskom okruženju.

12 FP7 projekt SELUSI (2011), Social Entrepreneurs as Lead Users for Service Innovation 
prema modelu integracije, ii) prema statusu radnika $\mathrm{u}$ integraciji te iii) prema modelima profesionalnog treninga.

Što se tiče i) modela integracije postoje četiri glavna integrativna modela socijalnih poduzeća za radnu integraciju: a) socijalna poduzeća za radnu integraciju koja promiču integraciju putem prijelazno-okupacijskih poslova čiji je cilj omogućiti ciljanoj skupini korisnika ,prijelazno“ radno iskustvo; b) socijalna poduzeća za radnu integraciju koja stvaraju trajne samofinancirajuće poslove koji imaju za svrhu stvaranje ekonomski samoodrživih poslova namijenjenih teško zapošljivim osobama; c) socijalna poduzeća za radnu integraciju koja osiguravaju profesionalnu integraciju s trajnim subvencijama koja su namijenjena najranjivijim grupama radnika na otvorenom tržištu rada, koji nisu u mogućnosti dobiti stalno zaposlenje. Oni se trajno financiraju iz lokalnih i državnih sredstava. Ciljane skupine ovog tipa socijalnih poduzeća dobrim su dijelom i osobe s invaliditetom; te naposljetku d) socijalna poduzeća za radnu integraciju koja osiguravaju socijalizaciju na temelju produktivnih aktivnosti, čiji cilj nije u profesionalnoj integraciji radnika na otvoreno tržište rada, nego u (re) socijalizaciji ciljanih skupina u društvo.

Nadalje, prema statusu radnika razlikujemo tri glavna tipa statusa radnika u integraciji (Davister i sur., 2004): a) radnik s formalnim ugovorom o radu, sukladno postojećem zakonodavstvu, b) status polaznika treninga, u kojem produktivan rad osigurava prije svega trening radi stjecanja iskustva te status vježbenika koji ne dobiva plaću i gdje je vježbeništvo obično ograničenog trajanja i c) okupacijski radni status, gdje se radom ostvaruje prilika za rad i resocijalizaciju ciljane grupe. Radni uvjeti ovdje su lakši negoli na otvorenom tržištu rada te su ponekad predviđene određene naknade.

Na kraju, socijalna poduzeća za radnu integraciju razlikujemo i prema modelima profesionalnog treninga, pa postoji: a) profesionalan trening „na poslu“, koji nastoji radniku osigurati potrebne informacije o njegovim/njezinim glavnim zadacima, o načinu korištenja strojeva, i o pravilima sigurnog upravljanja i kratkotrajnog je trajanja te b) strukturirani profesionalni trening koji je usmjeren na unaprjeđenje karakteristika (ručnog rada, kompjuterskih znanja, jezika itd.) i kvalifikacije radnika radi povećavanja njegove zapošljivosti na tržištu rada.

Iz svega navedenog stječe se dojam da postoji raširen entuzijazam za potencijal socijalnih poduzeća za radnu integraciju osoba u nepovoljnom položaju na tržišta rada (O'Connor, Meinhard, 2014.). Stoga ćemo sagledati njihov razvoj i ulogu koju imaju u radnoj integraciji ranjivih skupina u postsocijalističkim zemljama i posebno u Hrvatskoj.

\section{SOCIJALNA PODUZEĆA ZA RADNU INTEGRACIJU U POSTSOCIJALISTIČKIM ZEMLJAMA}

U ovom poglavlju analizirat ćemo zapošljavanje osoba s invaliditetom putem socijalnih poduzeća za radnu integraciju u post-socijalističkim europskim državama. Ključni kriterij prema kojemu smo vršili odabir zemalja za analizu jest članstvo u EU, te smo stoga odabrali Poljsku, Sloveniju, Slovačku i Češku kao države u kojima ćemo analizirati socijalna poduzeća za radnu integraciju kao aktere zapošljavanja osoba s invaliditetom. ${ }^{13}$

\section{Poljska}

Nakon političkih promjena 90-tih, socijalna poduzeća u Poljskoj počinju sa svojim djelovanjem u svrhu ublažavanja postojećih nejednakosti na tržištu rada, te socijalnom reintegracijom socijalno isključenih grupa i pojedinaca. Početkom 1990-te otvaraju se zaštitne radionice za osobe sa invaliditetom koje su bile organizirane od strane radnih terapijskih radionica sa svrhom socijalne reintegracije osoba sa invaliditetom (Ciepielewska-Kowalik i sur., 2015). Zakonom o socijalnoj rehabilitaciji i zapošljavanju osoba s invaliditetom (1997.) Poljska je utrla put razvoja koncepta socijalnih poduzeća za radnu integraciju promovirajući socijalnu integraciju osoba s invaliditetom putem socijalnih poduzeća i rehabilitacijskih programa. Nakon naknadnog dekreta Ministarstva rada i socijalne politike iz 2007. godine događaju se dva znakovita trenda: s

13 Poticaj za ovakvu komparaciju bio je općeniti nedostatak studija koje promatraju socijalna poduzeća za radnu integraciju u bivšim socijalističkim zemljama, posebno komparativnih studija. Socijalna poduzeća za radnu integraciju kao specifičan oblik socijalnog poduzetništva nije detaljno istražen u navedenim zemljama, te je literature malo, posebno na engleskom ili nama bliskim jezicima. 
jedne strane, događa se značajni porast strukovnih radionica za osobe sa invaliditetom; s druge strane, nakon 2003. godine događa se značajan pad broja (oko 50\%) zaštitnih radionica koje su bile financirane od strane države (Ciepielewska-Kowalik i sur., 2015). Profesionalna i socijalna reintegracija socijalno isključenih skupina temelji se na aktivnom pristupu (DIESIS, 2009).

Noviji podaci ukazuju na nastavak jačanja socijalnih poduzeća za radnu integraciju u Poljskoj. Izvješće Vladine skupine za osobe s invaliditetom (2014., prema Ciepielewska-Kowalik i sur., 2015) pokazalo je, na kraju 2013. godine, da je u Poljskoj aktivno djelovalo 1416 integrativnih i zaštitnih radionica, od čega su 79,91\% zaposlenika bile osobe $\mathrm{s}$ invaliditetom. Isto tako, bilježimo porast broja strukovnih radionica u periodu od 2012.-2014. s 58 na 70 organizacija (PFRON 2014., prema Ciepielewska-Kowalik i sur., 2015). ${ }^{14}$

Osim integrativnih, zaštitnih i strukovnih radionica, Poljska razvija i ostala socijalna poduzeća iz domene socijalnih poduzeća za radnu integraciju. Istraživanja (Chorążuk i sur., 2008, prema Ciepielewska-Kowalik i sur.; 2015; Paczynski i sur, 2014) bilježe i porast okupacijsko-terapijskih radionica u 2012. godini sa 608 na 670. Utvrđene su i neke specifičnosti okupacijsko- terapijskih radionica u Poljskoj. Više od $60 \%$ tih radionica bilo je osnovano i organizirano od strane nevladinih organizacija; aktivnosti tih poduzeća bile su usmjerene isključivo prema osobama s invaliditetom odnsono osobama s intelektualnim teškoćama, koje su činile više od $60 \%$ svih sudionika tih radionica. Fond za rehabilitaciju osoba s invaliditetom pokrivao je tim socijalnim poduzećima $97 \%$ troškova, što ide u prilog tezi njihove ograničene samo-održivosti. Poljska je razvila i specifičan organizacijski oblik zadruga specijaliziranih za rad s osobama s invaliditetom - zadruge za slijepe i zadruge za osobe $s$ invaliditetom. Takvih zadruga je u Poljskoj 2010. godine bilo 258 (Paczynski i sur., 2014). ${ }^{15}$

Poljska 2013. godine donosi dvije znakovite novine koje će dodatno doprinijeti razvoju socijalnih poduzeća za radnu integraciju (Paczynski i sur, 2014): a) Poljski Fond za zapošljavanje odlučio je izdvajati značajna sredstva za djelovanje socijalnih poduzeća. Osnivači novoosnovanih socijalnih zadruga imaju pravo na grantove u iznosu do 4 mjesečne plaće (cca 3000€); b) Fond za profesionalnu rehabilitaciju izdvojio je značajna sredstva kako bi motivirao osobe $\mathrm{s}$ invaliditetom da se uključe u rad socijalnih poduzeća za radnu integraciju. ${ }^{16}$

Identificirani su sljedeći nedostaci u pogledu razvoja socijalnih poduzeća za radnu integraciju u Poljskoj (Paczynski i sur., 2014): problem financijske održivost nekih vrsta socijalnih poduzeća za radnu integraciju koja se dominantno financiraju iz gradskih proračuna; nedovoljna osviještenost zajednice o aktivnostima socijalnih poduzeća; nedovoljna razina znanja i kompetencija u rješavanju problema vezanih uz poslovanje tih poduzeća i nedostatak poduzetničkog duha članova/vlasnika/ sudionika te ograničena potražnja za proizvodima i uslugama socijalnih poduzeća, posebice u javnoj nabavi.

\section{Slovenija}

Slovenija je tek nedavno počela razvijati pravni i strateški okvir u poticanju zapošljavanja osoba S invaliditetom putem socijalnog poduzetništva. ${ }^{17}$ U socijalnom sektoru počele su se razvijati radionice za osobe s invaliditetom, od kojih su nastala poduzeća za osobe s invaliditetom s uređenim statusom (Heckl i sur., 2007). Ulazak Slovenije u EU značajno utječe na oblikovanje politika razvoja socijalnih poduzeća za radnu integraciju, budući

14 Pokazuje se da je 56,9\% njih osnovano i organizirano od strane neprofitnih organizacija, a 43,1\% od lokalnih vlasti. Tek manjina strukovnih rehabilitacijskih postrojenja usmjerena je isključivo proizvodnji usluga $(24.5 \%)$ i dobara $(7,5 \%)$, ali većina njih kombiniraju te aktivnosti $(67,9 \%)$. Prodaju većina njih vrši na lokalnom tržištu $(73,1 \%)$. Najvažniji izvor financiranja strukovnih radionica je Državni fond za rehabilitaciju osoba sa invaliditetom, koji pokriva $82 \%$ troškova socijalnih poduzeća.

15 Osim tih podataka, nešto starije istraživanje (DESIS, 2009) navodi kako se WISE razvijaju u 4 tipa. Socijalne zadruge zapošljavaju 700 osoba (od čega 80\% u nepovoljnom položaju), 55 centara i klubova za socijalnu integraciju, koji zapošljavaju 1500 osoba (730 na ekvivalent punog radnog vremena), te 350 poduzeća za podršku integraciji (zadruga za osobe s invaliditetom).

16 Tako je taj fond predvidio grantove u visini čak 15 mjesečnih plaća za osobe s invaliditetom koji se kao članovi priključe novoosnovanim socijalnim poduzećima.

17 Iako kako navode Heckl i sur. (2007), sfera zapošljavanja osoba s invaliditetom dobro je razvijena i putem javnih zavoda za zapošljavanje, gdje mogu biti uključeni u rad, obrazovanje i određene vidove pomoći. 
da se upravo u tim godinama donose tri ključna dokumenta za razvoj socijalnih poduzeća za radnu integraciju u Sloveniji: Zakon o okupacijskoj rehabilitaciji za osobe s invaliditetom (2004.), Program za osobe s invaliditetom (2007-2013) i Zakon o socijalnom poduzetništvu (2011.) (prema Kadunc, i sur., 2014a).

Zakon o okupacijskoj rehabilitaciji za osobe s invaliditetom uvodi status trening zaštitnih radionica i socijalnih poduzeća, kako bi se omogućio trening osobama s invaliditetom na radnom mjestu. Nadalje, u tom zakonu se uvodi sustav kvota za zapošljavanje osoba $\mathrm{s}$ invaliditetom $\mathrm{u}$ privatnom sektoru i u zaštitnim i integrativnim radionicama. Vladin Program za osobe s invaliditetom (2007.2013.) kao jedan od glavnih ciljeva navodi osiguranje pristupa tržištu rada osobama sa invaliditetom i njihovo zapošljavanje bez diskriminacije $u$ radnom okruženju koje je otvoreno, inkluzivno i pristupačno (Kadunc, i sur., 2014a). Zakonom o socijalnom poduzetništvu (2011.) po prvi je puta u nacionalnim okvirima definirano socijalno poduzetništvo. Zakon je omogućio razlikovanje socijalnih poduzeća za radnu integraciju od ostalih vrsta socijalnih poduzeća te je bio osnova za usvajanje Nacionalne strategije za razvoj socijalnog poduzetništva za period 2013.-2016. Strategija je za taj period predvidjela sredstva u visini $2.530 .000 € \mathrm{za}$ subvencioniranje zapošljavanja ranjivih skupina.

Evaluacije razvoja socijalnih poduzeća za radnu integraciju i razina participacije osoba s invaliditetom u njima pokazuju određeni uspjeh. Tako 2006. godine od 263 osoba uključene u 21 aktivni trening zaštitnih radionica, tek polovica njih bile su osobe $\mathrm{s}$ invaliditetom. Razvoj trening zaštitnih radionica nije uspio i bio je korišten od strane malog broja savjetodavaca i rehabilitacijskih stručnjaka (Fatur i Vidmar, 2007, prema Kadunc, i sur., 2014a). S druge strane, utvrđen je značajan pomak u pogledu zapošljavanja osoba sa invaliditetom putem zaštitnih i integrativnih radionica. Istraživanje je tako pokazalo da se broj osoba zaposlenih u zaštitnim $\mathrm{i}$ integrativnim radionicama udvostručio $\mathrm{s} 1,587$ u 2006. godini na 3,016 u 2008. godini (ANED,
2008). Slovenija bilježi i porast broja poduzeća za osobe s invaliditetom ${ }^{18}$ sa 115 u 2008. na $142 \mathrm{u}$ 2014. godini (Kadunc, i sur., 2014a). Od velikog značaja za obrazovanje stručnjaka i djelatnika socijalnih poduzeća je i novoosnovani Centar za socijalno poduzetništvo, koji djeluje pri Ljubljanskom sveučilištu, osnovan u suradnji 6 različitih fakulteta.

Izvješće Europske komisije za razvoj socijalnog poduzetništva u Sloveniji (Kadunc i sur., 2014a) identificiralo je nekoliko nedostataka u poticanju zapošljavanja osoba s invaliditetom putem socijalnih poduzeća. Oni se odnose na ograničeni pristup financiranju, nedovoljnu educiranost radnika, menadžmenta i ostalih relevantnih dionika, neadekvatne politike koje nepovoljno utječu na socijalna poduzeća za radnu integraciju, slabu / nedovoljnu osviještenost javnosti o socijalnom poduzetništvu te de-motivirajuće faktore zapošljavanja osoba s invaliditetom koji tim osobama uvjetuju gubljenje određenih prava ukoliko se zaposle.

\section{Slovačka}

Slovačka tek ulaskom u EU definira javne politike kojima potiče razvoj socijalnog poduzetništva i socijalnih poduzeća za radnu integraciju. Tako se izglasavanjem Zakona o pružateljima zaposlenja (2008.) (prema Andruszkiewicz i sur., 2014) po prvi put definiralo socijalno poduzetništvo $i$ postavilo uvjete za razvoj socijalnih poduzeća za radnu integraciju. Taj zakon navodi da je socijalno poduzeće pravna ili fizička osoba koja zapošljava najmanje $30 \%$ radnika sa značajnim ograničenjima u zapošljavanju na otvorenom tržištu rada. ${ }^{19}$

U Slovačkoj porezni sustav igra značajnu ulogu u stvaranju prihoda za rad socijalnih poduzeća, budući da fizičke i pravne osobe mogu određeni dio poreza na dohodak (2-3\% za fizičke i $1.5 \%$ za pravne osobe) posvetiti i dodijeliti organizacijama civilnog društva. Organizacijama civilnog društva na ovaj je način 2004. godine bilo dodijeljeno 27 milijuna eura, dok je iznos tih sredstva 2009. bio dvostruko veći (55 milijuna) (Streĉanskŷ, 2011, prema Andruszkiewicz i sur., 2014)

18 Riječ je o posebnoj vrsti privatno- profitnih poduzeća u kojima se pretežno zapošljavaju osobe s invaliditetom, a kojima je prema važećem zakonu o socijalnom poduzetništvu onemogućeno da se registriraju kao socijalna poduzeća.

19 Iako postoje određene primjedbe (Sokol, 2010) da je upravo zakonska definicija uska i ograničavajuća za razvoj socio-poduzetničkih inicijativa u Slovačkoj. 
Prema statističkim izvještajima, u Slovačkoj se bilježi porast u zapošljavanju osoba s invaliditetom putem socijalnog poduzetništva. Tako Centar za rad, socijalne poslove i obitelj (2009., prema Andruszkiewicz i sur., 2014) navodi da je 8.614 osoba s invaliditetom bilo zaposleno u integrativnim i zaštitnim radionicama, dok je 2011. godine u 5.876 integrativnih i zaštitnih radionica radilo 10,783 osoba s invaliditetom (Andruszkiewicz i sur., 2014).

U Slovačkoj postoji i djeluje Unija proizvodnih zadruga - krovna organizacija koja objedinjuje preko 81 proizvodnu zadrugu, unutar kojih djeluje 60 zaštitnih radionica koje zapošljavaju preko 300 osoba s tjelesnim invaliditetom (Strečanský i Stoláriková, 2012).

Barijere razvoja socijalnih poduzeća za radnu integraciju u Slovačkoj (Andruszkiewicz i sur., 2014) uključuju: nedostatna sredstva za financiranje socijalnih poduzeća, posebice smanjenje najviše razine sufinanciranja plaća radnicima koji rade u socijalnim poduzećima ${ }^{20}$, nisku razinu socijalnog kapitala, uzimajući da je broj dionika uključenih u proces razvoja socijalnog poduzetništva $u$ Slovačkoj fragmentiran i malobrojan, te nedovoljan stupanj kompetencija i stručnosti socijalnih poduzeća, kao i nedovoljnu svijest i razumijevanje koncepta (Sokol, 2010). Kao važan faktor razvoja socijalnog poduzetništva, pa tako i onog za integraciju, navodi se porast potražnje za socijalnim uslugama, kako bi se bolje naslovile specifične potrebe u kontekstu ograničenih kapaciteta države i javnih politika (Heckl i sur., 2007).

\section{Češka}

Češka je također tek nedavno javnim politikama počela razvijati socijalno poduzetništvo. Ulazak Češke u EU pozitivno utječe na razvoj socijalnog poduzetništva. Češka donosi dva strateška dokumenta kojima postavlja uvjete za razvoj socijalnog poduzetništva: Akcijski plan za socijalnu integraciju (2008-2010.) i Nacionalni plan pomoći u integraciji osoba s invaliditetom za 2010-2014 (prema Caisl i sur., 2014). Međutim, Češka ne donosi zakon kojim bi uredila područje socijalnog poduzetništva. Zakonodavac je tek Zakonom o trgovačkim društvima iz 2014. godine (prema Caisl i sur., 2014) definirao socijalnu zadrugu kao jedini institucionalizirani oblik socijalnog poduzeća, iako izrekom nije spriječio druge oblike organizacija civilnog društva da se bave socijalnim poduzetništvom.

Češki Zakon o zapošljavanju iz 2004. godine (prema Caisl i sur., 2014) predviđa dva oblika financijske potpore socijalnim poduzećima za radnu integraciju: financijsku potporu radi otvaranja radnog mjesta za osobu s invaliditetom, pri čemu se iznos tih sredstava određuje prema stupnju invaliditeta te predviđa sredstva i u visini 12 prosječnih plaća, te financijsku potporu poslodavcu koji zapošljava osobe s invaliditetom u iznosu 75\% plaće. Sredstva za ovaj oblik potpore osiguravaju se iz fonda ustrojenog pri Uredu za zapošljavanje. Također, od 2009. godine postoje tri javne sheme namijenjene isključivo socijalnim poduzećima za radnu integraciju, s kriterijem da najmanje 40\% radne snage moraju biti osobe $\mathrm{s}$ invaliditetom ili druge osobe iz posebno ugroženih skupina.

Prema tipu socijalnih poduzeća, u Češkoj su najviše razvijena upravo socijalna poduzeća za radnu integraciju. Istraživanje koje su provele neprofitne organizacije People, Planet, Profit i Provida (2013, prema Caisl i sur., 2014) pokazuje da je čak $72 \%$ socijalnih poduzeća u Češkoj usmjereno prema osobama s invaliditetom. Drugo istraživanje iste neprofitne organizacije (People, Planet, Profit, 2014, prema Caisl i sur., 2014) pokazuje da su socijalna poduzeća za radnu integraciju zapravo najrazvijenija i najraširenija vrsta socijalnih poduzeća u Češkoj te su jedina zapravo zakonski prepoznata (Dohnalová i sur,. 2015.).

Utvrđen je i određeni napredak glede educiranja studenata o socijalnom poduzetništvu u Češkoj. Fakultet društvenih znanosti pri Charlesovom Sveučilištu sustavno razvija područje socijalne ekonomije i poduzetništva, koji uključuje obavezni kolegij iz socijalne ekonomije već od 2006. godine. (Caisl i sur., 2014). Češka je napravila značajan pomak i glede provedbe kampanja senzibilizaci-

20 Amandmanom na Zakon o zapošljavanju smanjen je iznos najviše razine sufinanciranja za plaće radnicima u socijalnim poduzećima s 50\% ukupne plaće na $25 \%$ prosječne plaće u bratislavskoj regiji, odnosno na $30 \%$ prosječne plaće u drugim regijama gdje je stopa nezaposlenosti niža od nacionalnog prosjeka, odnosno na $40 \%$ prosječne plaće u onim regijama gdje je stopa nezaposlenosti viša od nacionalnog prosjeka. 
je javnosti o ulozi socijalnih poduzeća za razvoj zajednice. Tako je OPHRE-ov projekt (Caisl i sur., 2014) Inovativna utemeljenost socijalnog poduzetništva okupio niz dionika koji na regionalnim razinama upoznaju širu javnost sa socijalnim poduzetništvom putem seminara i panel rasprava. ${ }^{21}$

Nedostaci i barijere u razvoju socijalnih poduzeća za radnu integraciju u Češkoj su (Caisl i sur., 2014) nepostojanje kontinuiranog izvora financiranja socijalno - poduzetničkih projekata na nacionalnoj razini, nedovoljna educiranost organizacija civilnog društva o socijalnom poduzetništvu ${ }^{22}$ te pouzdanje u državu pri rješavanju svih problema (Heckl, i sur, 2007).

\section{SOCIJALNO PODUZETNIŠTVO U REPUBLICI HRVATSKOJ}

U hrvatskom kontekstu socijalno poduzetništvo još je u povojima. Kao glavni faktor zakašnjelog razvoja socijalnog poduzetništva u Hrvatskoj vide se represivnost vlasti bivšeg socijalističkog režima i loša percepcija javnosti prema organizacijama civilnog društva (Vidović, 2013). Iako postoje određene povijesne zasade, ono se značajnije pojavljuje u diskursu u Hrvatskoj prije 10-tak godina posredstvom stranih donatora koji su financijski i tehnički željeli doprinijeti razvitku koncepta (Vidović i Baturina, 2016).

Još uvijek ne postoji dovoljna informiranost o tome što socijalno poduzetništvo predstavlja te koji bi pozitivni utjecaj ono moglo imati na život društva. Ono nije zasebni pravni oblik, već status koji organizacija po naravi svog djelovanja i misi- je ima. Međutim, zakoni ne zabranjuju djelovanje takvih organizacija. Socijalna poduzeća najčešće su hibridne organizacije koje se pojavljuju unutar udruga zadruga, trgovačkih društava s ograničenom odgovornošću i privatnih ustanova (Vidović, 2013; Baturina, 2016). Nedavno usvojena Strategija razvoja društvenog ${ }^{23}$ poduzetništva u Republici Hrvatskoj za razdoblje od 2015. do 2020. godine propisuje definicijski što socijalno poduzetništvo predstavlja u hrvatskim uvjetima ${ }^{24}$. U njoj se socijalno/društveno poduzetništvo definira kao ,poslovanje temeljeno na načelima društvene, okolišne i ekonomske održivosti, kod kojeg se stvorena dobit/ višak prihoda u cijelosti ili većim dijelom ulaže za dobrobit zajednice“ (Vlada RH, 2015).

Važnu ulogu u limitiranju većeg razvoja socijalnog poduzetništva čine i socio-kulturni čimbenici vezani uz kolektivna iskustva iz prošlosti, koji su stvorili animozitet prema pojedinim aspektima socijalnog poduzetništva (Vidović, 2012). Identificirani su problemi vezani uz financiranje ${ }^{25}$, što je ograničavajući čimbenik pri osiguravanju autonomnosti djelovanja, te nedostatak kapaciteta ljudskih resursa i stručnosti potrebnih za pokretanje socijalnog poduzetništva (Vidović, 2012; Vincetić, i sur., 2013).

Očekuje se da će nova strategija razvoja društvenog poduzetništva biti zalog razvoja sektora. ${ }^{26}$ Međutim očekuju je značajni izazovi u provedbi, poput izazova vođenja evidencije i baze aktera na terenu, načina uvođenja i modela izračuna društvenog utjecaja i drugo (iPRESENT, 2015). Kapaciteti za njezinu primjenu bit će dvojbeni posebice jer se ona dotiče brojnih područja u kojima nedostaje modernizacijskih kapaciteta i horizontalne i ver-

21 Također projekt je, zajedno s Integrated Operational Programme (IOP) podržao oko 150 socijalnih poduzeća, većinom socijalna poduzeća za radnu integraciju.

22 Pri tome su krajnje indikativni nalazi istraživanja u okviru Izvješća Europske komisije o razvoju socijalnog poduzetništva u Češkoj (Caisl i sur., 2014.), koje je pokazalo da oko 100 organizacija koje zadovoljavaju kriterije bavljenja socijalnim poduzetništvom (dakle, bave se socijalnim poduzetništvom) uopće ne znaju što socijalno poduzetništvo kao koncept jest.

23 Držimo da naknadno uveden termin „društveno poduzetništvo“ nije prikladan, već bi se trebao koristiti pojam „,socijalno poduzetništvo“, što i koristimo u ovom radu. Naime kada pogledamo korištenje terminologije socijalnog u drugim izrazito bliskim i vezanim kontekstima, iskustva drugih zemalja slične jezične tradicije, ukorijenjenost u stručnoj i znanstvenoj javnosti te dosadašnja iskustva relevantnih dokumenata i strategija, ne nalazimo niti jedan argument za preimenovanje termina. U tom smo smislu poslali primjedbe radnoj skupini koja je izrađivala Strategiju

24 Definicija, kao i sami kriteriji, na neki su način pokušali pomiriti i obuhvatiti više različitih načina promatranja socijalnog poduzetništva, ali su uvelike bliski pristupu razvijenom od EMES mreže (više o pristupu u Defourny, 2001; Defourny i Nyssens, 2012).

25 Iako je financiranje značajan problem koji bi pridonio većem ekonomskom utjecaju u Hrvatskoj, inovativni mehanizmi financiranja nisu razvijeni (Kadunc i sur., 2014b).

26 Usvojena verzija Strategije ima devet kriterija koji moraju biti ispunjeni da bi se nekoga smatralo socijalnim poduzetnikom. Kao ciljevi u njoj se navode uspostava i unapređenje zakonodavnog i institucionalnog okvira za razvoj društvenog poduzetništva; uspostava financijskog okvira za učinkovit rad društvenih poduzetnika; promicanje važnosti i uloge društvenog poduzetništva kroz formalne i neformalne oblike obrazovanja; osiguranje vidljivosti uloge i mogućnosti društvenog poduzetništva u Republici Hrvatskoj te informiranje opće javnosti o temama u vezi s društvenim poduzetništvom. 
Luka Marković, Danijel Baturina, Zdenko Babić: Socijalna poduzeća za radnu integraciju (WISE) u postsocijalističkim zemljama

Tablica 1. Broj zaposlenih i nezaposlenih osoba s invaliditetom po godinama ${ }^{27}$

\begin{tabular}{|l|l|l|l|l|l|l|l|l|l|l|l|}
\hline Godina & $\mathbf{2 0 0 5}$ & $\mathbf{2 0 0 6}$ & $\mathbf{2 0 0 7}$ & $\mathbf{2 0 0 8}$ & $\mathbf{2 0 0 9}$ & $\mathbf{2 0 1 0}$ & $\mathbf{2 0 1 1}$ & $\mathbf{2 0 1 2}$ & $\mathbf{2 0 1 3}$ & $\mathbf{2 0 1 4}$ & $\mathbf{2 0 1 5}$ \\
\hline Zaposleni & 1034 & 1211 & 1423 & 1267 & 1028 & 1080 & 1465 & 1421 & 1744 & 1877 & 2613 \\
\hline Nezaposleni & 5892 & 5790 & 5703 & 5579 & 6215 & 6255 & 5992 & 6607 & 6789 & 6789 & 7303 \\
\hline
\end{tabular}

Izvor: Hrvatski zavod za zapošljavanje

tikalne koordinacije među ključnim dionicima (Baturina, 2016).

Potrebno se kratko osvrnuti i na položaj osoba sa invaliditetom na tržištu rada. $U$ izvješćima o aktivnostima Hrvatskoga zavoda za zapošljavanje $\mathrm{u}$ području zapošljavanja osoba s invaliditetom možemo pratiti broj zaposlenih i nezaposlenih osoba s invaliditetom kroz duži vremenski period. Pokazuje se da zadnjih nekoliko godina raste broj osoba koje se zapošljavaju iz evidencije Hrvatskoga zavoda za zapošljavanje, uz istovremeni porast broja nezaposlenih u evidenciji Hrvatskog zavoda za zapošljavanje. Naime, takva tendencija može se objasniti činjenicom da je priljev u evidenciju nezaposlenih osoba s invaliditetom veći od odljeva u zaposlenost iz baze HZZ-a, te uslijed toga dolazi do porasta ukupnog broja nezaposlenih osoba $\mathrm{s}$ invaliditetom $\mathrm{u}$ evidenciji nezaposlenih. Prema podacima Izvješća Hrvatskog zavoda za javno zdravstvo (HZJZ, 2015), u Hrvatskoj je u ožujku 2015. godine bilo 508350 osoba s invaliditetom, što čini $12 \%$ ukupnog stanovništva Republike Hrvatske. Najveći broj osoba s invaliditetom, njih 259887 ili 51,1 \% bilo je u radno aktivnoj dobi. U evidenciji Hrvatskog zavoda za zapošljavanje 30. rujna 2015. godine (HZZ, 2015) bilo je registrirano 6786 nezaposlenih osoba s invaliditetom što iznosi $2.6 \%$ populacije nezaposlenih osoba prijavljenih u evidenciju HZZ-a.

Godine 2014. najveći broj čine nezaposlene osobe od 20. do 34. godine života odnosno osobe u radno najaktivnijoj dobi života te su velikom većinom to bile osobe sa srednjoškolskim obrazovanjem (Vajda Halal, i sur., 2014). Izvješće MOBMS (2009) pokazuje da postoji značajna razlika u obrazovanju zaposlenih i nezaposlenih osoba s invalidi- tetom, pri čemu su zaposleni češće i obrazovaniji. Iz podataka prikazanih u tablici 1 . u zadnjih desetak godina uočava se trend rasta zapošljavanja osoba s invaliditetom iz evidencija Hrvatskog zavoda za zapošljavanje, čemu su zasigurno pridonijele pozitivne zakonodavno-institucionalne promjene u segmentima koji reguliraju ovo područje, kao što su promjene u segmentu kvotnog zapošljavanja, uvođenja obveza poslodavca koji zapošljavaju više od 20 zaposlenih da zaposle osobu s invaliditetom, ili da umjesto toga plate naknadu u Fond za profesionalnu rehabilitaciju i zapošljavanje, iz kojega se onda povratno financiraju programi za zapošljavanje osoba s invaliditetom. Međutim, istovremeno s porastom zapošljavanja razvidan je i porast broja prijavljenih nezaposlenih osoba $\mathrm{s}$ invaliditetom $\mathrm{u}$ evidenciji zavoda za zapošljavanje te zapošljavanje osoba s invaliditetom i nadalje predstavlja značajan izazov za Hrvatsko društvo. ${ }^{27}$

Međutim, iako je došlo do određenih pomaka posljednjih nekoliko godina, integracija osoba s invaliditetom u svijet rada ipak značajno zaostaje za napretkom koji je ostvaren u području zakonodavno-institucionalne infrastrukture ${ }^{28}$ (Babić, Leutar, 2010). Jedna od glavnih prepreka njihovom zapošljavanju jest činjenica da značajan dio tih osoba nema radnog staža te je velik dio njih izrazito dugotrajno nezaposlen (Vajda Halal, i sur., 2014; Kiš Glavaš i sur., 2008), što dalje ukazuje na potrebu za aktivnim mjerama zapošljavanju upravo i jačanjem socijalnih poduzeća za radnu integraciju osoba s invaliditetom. Zapošljavanje uz potporu Kiš-Glavaš (2009) upravo ističe kao najučinkovitiji model za poticanje zapošljavanja osoba $\mathrm{s}$ invaliditetom ${ }^{29}$, a koje postoji i primjenjuje se u svijetu već duže vremena te može biti okvir

27 Izvor: Izvješće o aktivnostima Hrvatskoga zavoda za zapošljavanje u području zapošljavanja osoba s invaliditetom u razdoblju od 01. siječnja do 31. prosinca 2015. godine i Izvješće o aktivnostima Hrvatskoga zavoda za zapošljavanje u području zapošljavanja osoba s invaliditetom u razdoblju od 01. siječnja do 31. prosinca 2014. godine.

28 Kao neke od dijelova možemo izdvojiti Nacionalnu strategiju izjednačavanja mogućnosti za osobe s invaliditetom 2007-2015, postojanje instituta pravobraniteljice za osobe sa invaliditetom, Zakon o profesionalnoj rehabilitaciji i zapošljavanju osoba s invaliditetom, kao i postojanje posebnog Fonda za profesionalnu rehabilitaciju i zapošljavanje osoba s invaliditetom.

29 Više se osvrćući specifično na osobe s intelektualnim teškoćama. 
za razvoj socijalnih poduzeća za radnu integraciju. Slično tome, savjetnici HZZ-a procjenjuju da je sufinanciranje najučinkovitija mjera za zapošljavanja osoba s invaliditetom (Human Dynamics, 2010). S druge strane, same osobe s invaliditetom (prema Kiš Glavaš i sur., 2008) nešto više preferiraju zapošljavanje na otvorenom tržištu rada nego zaštitne radionice. Iako podaci prikazani u tablici 1 upućuju na određene pozitivne pomake u pogledu porasta zapošljavanja osoba s invaliditetom uslijed navedenih pozitivnih zakonskih i institucionalnih promjena, ti pozitivni pomaci ipak su još uvijek nedovoljni, s obzirom da je ukupan broj nezaposlenih osoba s invaliditetom u kontinuiranom porastu, te da i dalje vrijedi nalaz da poslodavci nedovoljno podržavaju zapošljavanje i rad osoba s invaliditetom (Kiš-Glavaš, 2002).

Istraživanje pod naslovom Socijalni položaj osoba s invaliditetom u Hrvatskoj (2009) pokazalo je da zaposlene sobe s invaliditetom imaju veću uključenost $\mathrm{u}$ život lokalne zajednice i socijalnu integraciju te imaju bolje materijalne prilike. Također Leutar i Milić Babić (2008) pokazuju da je materijalna situacija lošija kod nezaposlenih osoba s invaliditetom. Oni češće žive s roditeljima te su manje zadovoljne životom. Prema Kiš Glavaš i sur. (2008) nezaposlene osobe s invaliditetom iskazuju nezadovoljstvo svojom situacijom te zapošljavanje predstavlja jedan od ključnih faktora njihove kvalitete života. U tom kontekstu potrebno je istražiti mogućnosti socijalnih poduzeća za radnu integraciju.

Iako je u vrijeme socijalizma postojala određena tradicija radne integracije ${ }^{30}$, pristup radnoj integraciji u vidu socijalnog poduzetništva u nas je novijeg datuma. Godine 2005. zakonodavac je po prvi puta Zakonom o profesionalnoj rehabilitaciji i zapošljavanju osoba s invaliditetom definirao dva glavna oblika socijalnih poduzeća za radnu integraciju: integrativnu i zaštitnu radionicu. Postojećim Zakonom o profesionalnoj rehabilitaciji i zapošljavanju osoba s invaliditetom (NN 157/13, 152/14) integrativna radionica definirana je kao ustanova ili trgovačko društvo koje je osnovano radi zapošljavanja osoba s invaliditetom koje se ne mogu zaposliti na otvorenom tržištu rada, koje zadovoljava kadrovske, tehničke i organizacijske uvjete, te zapošljava najmanje $40 \%$ osoba s invaliditetom u odnosu na ukupan broj zaposlenih (čl.18). Zaštitna radionica definirana je kao ustanova ili trgovačko društvo koje se osniva radi zapošljavanja osoba s invaliditetom koje se ne mogu zaposliti u integrativnim radionicama, a koje ispunjava kadrovske, tehničke i organizacijske uvjete propisane posebnim pravilnikom, te zapošljava najmanje 51\% osoba s invaliditetom u odnosu na ukupni broj zaposlenih, i to isključivo na zaštitnim radnim mjestima (čl.20). Kvote za zapošljavanje osoba s invaliditetom u ovim oblicima, koji su prototipovi socijalnih poduzeća za radnu integraciju, više su nego u nekim drugim zemljama.

Godine 2007. godine dogodile su se dvije značajne stvari za razvoj socijalnog poduzetništva u Hrvatskoj. Prvo, te godine Vlada donosi Nacionalnu strategiju izjednačavanja mogućnosti za osobe s invaliditetom od 2007. do 2015. godine, gdje se u poglavlju „Profesionalna rehabilitacija, zapošljavanje $i$ rad" kao jedna od mjera navodi utvrđivanje ,modela pri zapošljavanju osoba s invaliditetom koje se ne mogu zaposliti na otvorenom tržištu rada bez podrške ${ }^{31}$ i osiguravanje mjera provođenja podrške pri zapošljavanju“. Time se po prvi puta u nekom strateškom dokumentu RH indirektno poticao razvoj socijalnih poduzeća za radnu integraciju. Međutim, zbog nekonzistentne i nepotpune provedbe Strategije, kao i relativnog nepoznavanja koncepta socijalnog poduzetništva, spomenuta mjera nije u cijelosti zaživjela. Pozitivne promjene uočene su u segmentu socijalnih zadruga, čije je djelovanje omogućeno donošenjem Zakona o zadrugama tek 2011. godine.

Drugo, te iste 2007. godine Hrvatska s EU potpisuje Zajednički memorandum o socijalnom uključivanju, te je iste godine Hrvatskoj omogućen pristup IPA predpristupnim fondovima, gdje se po prvi put izdvajaju značajna sredstva za razvoj socijalnog poduzetništva u RH. Dakle, kako je već spomenuto, tek se sa Zakonom o zadrugama iz 2011. godine definirao prikladan registracijski

30 Primjerice Ustanova URIHO za profesionalnu rehabilitaciju i zapošljavanje osoba s invaliditetom pravni je sljednik najstarije zaštitne radionice u Hrvatskoj, koja je djelovala pod nazivom "Ivančica”, a bila je osnovana 1946. godine u Zagrebu. Ili pak DES (akronim od ,defektni sluhom“), koji je osnovan 1949. godine kao Poduzeće za zapošljavanje invalida DES Split, i to sa 20 zaposlenih, te je već 1956. godine počelo obavljati i djelatnost profesionalne rehabilitacije.

31 Koji primjerice mogu biti agencije, zadruge, radionice udruga za osobe s invaliditetom, radni asistenti. 
pravni oblik nositelja socijalnog poduzetništva koji zapošljava osobe s invaliditetom - u segmentu zadrugarstva, tipom socijalnih zadruga. ${ }^{32}$

Godine 2015. godine usvaja se Strategija razvoja društvenog poduzetništva u Republici Hrvatskoj za razdoblje od 2015. do 2020. godine. Strategijom su predviđa čitav niz aktivnosti kojima će se poticati stvaranje uvjeta i odgovarajućeg zakonodavnog okvira za kvalitetan razvoj socijalnog poduzetništva. Strategija donosi značajni financijski stimulans za razvoj socijalnog poduzetništva. ${ }^{33}$ Također Zavod za vještačenje, profesionalnu rehabilitaciju i zapošljavanje osoba s invaliditetom u svojem je Programu poticaja pri zapošljavanju osoba s invaliditetom za 2015-2016 godinu predvidio potpore u iznosu 29.900.000 kuna radi zapošljavanja osoba $\mathrm{s}$ invaliditetom putem integrativnih i zaštitnih radionica. Navedeni financijski okvir predstavlja i određeni potencijal iz kojeg bi se mogla osigurati sredstva za rad i poslovanje socijalnih poduzeća za radnu integraciju u Hrvatskoj.

Za sada stanje i razvoj socijalnih poduzeća za radnu integraciju u Hrvatskoj nije zavidno. Hrvatska je zabilježila značajan pad broja radnih i zaštitnih radionica u proteklih 20-tak godina. Prije 20-tak godina u Hrvatskoj je bilo aktivno 39 radionica s ukupno 3500 zaposlenih, dok je 2010.godine aktivno tek 6 zaštitnih radionica i 4 radne jedinice, s ukupno 560 zaposlenih (Human Dynamics, 2010). Također, od 2012. godine djeluje udruga OSVIT, koja predstavlja udrugu ustanova, drugih pravnih osoba i građana Republike Hrvatske, koji provode profesionalnu rehabilitaciju i zapošljavanje osoba $\mathrm{s}$ invaliditetom. Ona za sada ima 18 članica i može pružiti potporu razvoju socijalnih poduzeća za radnu integraciju. ${ }^{34}$ Podaci o trendovima kretanja točno određenih registracijskih pravnih oblika socijalnih poduzeća za radnu integraciju ne vode se na razini službenih statistika te ne postoji javno tijelo nadležno za vođenje evidencije ili podataka o socijalnim poduzećima za radnu integraciju.

Financiranje socijalnih poduzeća za radnu integraciju u Hrvatskoj problematično je kako na razini lokalne samouprave, tako i na nacionalnoj razini. ${ }^{35}$ Značajna ograničenja u razvoju socijalnog poduzetništva za radnu integraciju mogu se pripisati i nedovoljnoj educiranosti članova socijalnih poduzeća o socijalnom poduzetništvu (Vidović, 2012). Isto tako nedovoljan je javni prostor za oglašavanje i promidžbu socijalnih poduzeća i senzibilizaciju javnosti o važnosti socijalnog poduzetništva. U Hrvatskoj do sada nije provedena niti jedna kampanja na nacionalnoj razini koja bi senzibilizirana javnost o vrednotama i ulozi socijalnih poduzeća za radnu integraciju u zapošljavanju osoba s invaliditetom. Ne postoji krovna organizacija koja bi promicala socijalno poduzetništvo za radnu integraciju, a znanstvena istraživanja ovih tema rijetka su i neadekvatno zastupljena u akademskoj zajednici.

\section{USPOREDBA ISKUSTAVA POSTSOCIJALISTIČKIH ZEMALJA GLEDE SOCIJALNOG PODUZETNIŠTVA ZA RADNU INTEGRACIJU}

Socijalna poduzeća za radnu integraciju u postsocijalističkim europskim zemljama karakterizira zakašnjeli razvoj. Najveći dio zemalja uključenih u analizu svoj je zakonodavno- institucionalni okvir razvoja socijalnih poduzeća za radnu integraciju počeo razvijati tek početkom 2000-tih. Samo je Poljska taj okvir počela razvijati u ranim 90-tima ${ }^{36}$. Za razliku od drugih europskih država, postsocijalističke države počinju pristupati EU tek 2004. godine i jedan dio razvoja socijalnih podu-

32 Tako Zakon o zadrugama (NN 34/11, 125/13, 76/14) definira socijalnu zadrugu kao vrstu zadruge koja se osniva radi: obavljanja djelatnosti kojima se pruža pomoć u zadovoljenju osnovnih životnih potreba socijalno ugroženim, nemoćnim i drugim fizičkim osobama, koje one same ili uz pomoć članova obitelji ne mogu zadovoljiti zbog nepovoljnih osobnih, gospodarskih, socijalnih i drugih okolnosti; uključivanja u radne i gospodarske procese osoba s umanjenom radnom sposobnošću i drugih fizičkih osoba koje nemaju dovoljno sredstava za podmirenje osnovnih životnih potreba, a nisu u mogućnosti ostvariti ih svojim radom ili prihodom od imovine ili iz drugih izvora.

33 Osim toga postoje dva europska fonda na koje Hrvatska može aplicirati i tražiti sredstva za djelovanje socijalnih poduzeća za radnu integraciju: Europski EaSI program te Europski fond za socijalno poduzetništvo.

34 Neki od ciljeva organizacije upravo su i unapređivanje profesionalne rehabilitacije i zapošljavanja osoba s invaliditetom te kreiranje novih oblika i sadržaja rada osoba s invaliditetom.

35 Preliminarni rezultati ICSEM-ovog istraživanja o socijalnom poduzetništvu u Hrvatskoj, na temelju malog uzroka, pokazali su da tek trećina analiziranih socijalnih poduzeća ostvaruje neki oblik potpore od strane lokalnih vlasti.

36 Iako su načelno sve analizirane postsocijalističke države postale neovisne početkom 90-tih godina, u njima se tek sredinom 2000 -tih donose prvi zakoni kojima se uređuje područje socijalnog poduzetništva i socijalnih poduzeća za radnu integraciju. 
zeća za radnu integraciju može se vidjeti kao efekt kognitivne europeizacije, nametanja ovih tema iz diskursa EU i dostupnih fondova financiranja.

U većini analiziranih država postoji niska razina podrške javnosti za razvoj socijalnog poduzetništva. Komparativna analiza pokazuje da su u odnosu na zapadne članice Europske unije, socijalna poduzeća u Jugoistočnoj Europi manje razvijena i prepoznatljiva (Galera, 2016, ICF, 2014). Upravo nepostojanje legitimiteta javnosti i slaba razina socijalnog kapitala, dijelom uzrokovanog i kolektivnim iskustvima iz prošlosti (kao primjerice $u$ Hrvatskoj; više u Vidović, 2012), onemogućila su neprofitnom sektoru da se samoinicijativno organizira za ove svrhe i tako doprinese razvoju socijalnog poduzetništva za radnu integraciju. U većini analiziranih zemalja postoje fakulteti na kojima se izvode neki kolegiji iz područja socijalnog poduzetništva, što može biti poticaj za razvoj znanja i vještina u ovom području ali i zagovaranja u javnosti.

Utvrdili smo nekoliko općih obilježja razvoja socijalnih poduzeća za radnu integraciju u analiziranim državama. Sve analizirane post-socijalističke zemlje razvile su neki oblik financiranja socijalnih poduzeća za radnu integraciju. Poljska, Slovenija, Češka i Hrvatska razvile su fondove iz kojih financiraju djelovanje socijalnih poduzeća za radnu integraciju; Poljski fond za zapošljavanje i fond za profesionalnu rehabilitaciju dodjeljuju sredstva čak i osnivačima prilikom osnivanja socijalne zadruge, odnosno osobama $\mathrm{s}$ invaliditetom da se uključe u djelovanje novoosnovanih socijalnih poduzeća; Hrvatska i Slovenija nacionalnim su strategijama predvidjele dodatne oblike potpore za djelovanje socijalnih poduzeća za radnu integraciju.

Sve analizirane države imaju neki zakonodavno-institucionalni okvir putem kojeg osiguravaju razvoj socijalnog poduzetništva za radnu integraciju. Tako su Poljska, Slovenija i Hrvatska u okviru svojih zakona o rehabilitaciji i zapošljavanju osoba $\mathrm{s}$ invaliditetom počele razvijati socijalno poduzetništvo za radnu integraciju. Većina analiziranih država (Slovenija, Češka, Hrvatska) donijele su barem jedan nacionalni dokument (akcijski plan ili nacionalnu strategiju) kojim dodatno potiču razvoj socijalnog poduzetništva za radnu integraciju. Načelno je na sve analizirane zemlje značajan utjecaj u donošenju zakona i nacionalnih dokumenata kojima se stvaraju uvjeti za razvoj socijalnog poduzetništva za radnu integraciju, imala Europska unija.

Nadalje, utvrdili smo niz specifičnih obilježja glede djelovanja i funkcioniranja socijalnih poduzeća za radnu integraciju u analiziranim državama. Poljsku karakterizira visok stupanj decentralizacije glede organiziranja i upravljanja socijalnim poduzećima za radnu integraciju od strane lokalnih vlasti. To je jedina analizirana zemlja koja je uspjela uspostaviti adekvatan izvor financiranja socijalnih poduzeća za radnu integraciju u smislu održivosti i visine predviđenih sredstva. Poljsku karakterizira razvoj posebne vrste pravnog oblika socijalnih poduzeća za radnu integraciju koje druge analizirane države nisu razvile - zadruge za slijepe i zadruge za osobe s invaliditetom. Poljska također ima prilično razvijena socijalna poduzeća radno-okupacijskog karaktera. Uz to, znatno više istraživanja na temu razvoja socijalnih poduzeća za radnu integraciju provedeno je u Poljskoj negoli u drugim analiziranim državama.

Slovenija se pokazala kao jedina postsocijalistička zemlja koja je donijela konkretan zakon kojim je uredila područje socijalnog poduzetništva - Zakon o socijalnom poduzetništvu. Slovenija je isto tako razvila posebnu podvrstu pravnog oblika socijalnih poduzeća za radnu integraciju - poduzeća za osobe s invaliditetom. No, s druge strane $u$ Sloveniji broj socijalnih poduzeća za radnu integraciju nije velik te ona zapošljavanju mali broj osoba.

Slovačku, naspram ostalih postsocijalističkih država, karakteriziraju dva glavna obilježja u pogledu razvoja socijalnih poduzeća za radnu integraciju: postojanje nacionalne krovne organizacije, koja ima funkciju koordinatora i promicatelja suradnje na razini značajnog broja socijalnih poduzeća za radnu integraciju u državi, te financiranje socijalnih poduzeća kao i drugih dijelova civilnog društva putem poreznog sustava.

Zanimljivo obilježje u Češkom pristupu razvoja socijalnog poduzetništva jest dominacija socijalnih poduzeća za radnu integraciju naspram ostalih oblika socijalnih poduzeća. U pogledu razvoja socijalnih poduzeća za radnu integraciju češki zakonski okvir nam je interesantan zato što definira socijalnu 
zadrugu kao jedini institucionalni oblik socijalnog poduzeća.

Hrvatsku karakterizira značajno kasniji razvoj socijalnog poduzetništva naspram ostalih analiziranih postkomunističkih zemlja. Iako je Hrvatska već u periodu 2005-2011. godine donijela neke značajne zakone kao preduvjet razvoja socijalnih poduzeća za radnu integraciju, donosila je nekonzistentne nacionalne strategije koje nisu stvorile potrebne uvjete i okvir za razvoj te vrste socijalnog poduzetništva. Socijalna poduzeća za radnu integraciju u Hrvatskoj su malobrojna i ne zapošljavanju velik broj zaposlenika.

Kao poseban nedostatak analiziranih država vidi se i nepostojanje istraživanja o nekim specifičnim temama glede socijalnih poduzeća za radnu integraciju. Primjerice, nisu provedena istraživanja o tome koji je udio socijalnih poduzeća za radnu integraciju financiran iz kojih sredstava (iz lokalnog, regionalnog, državnog proračuna, odnosno iz europskih fondova), kako su socijalna poduzeća za radnu integraciju zastupljena s obzirom na pravne oblike (tj. koliko je socijalnih poduzeća za radnu integraciju registrirano kao udruga, zadruga, socijalna zadruga, društvo s ograničenom odgovornosti). Isto tako manjka konzistentnijih istraživanja o općim i specifičnim obilježja socijalnih poduzeća za radnu integraciju, kao i njihovom utjecaju na zapošljavanje i kvalitetu života osoba koje su njihovi dionici.

\section{ZAKLJUČAK}

Ovim smo radom analizirali socijalna poduzeća za radnu integraciju, koja su uvelike usmjerena prema integriranju osoba s invaliditetom u svijet rada i društvo putem produktivnih aktivnosti odnosno zapošljavanja. Analizu smo provodili u okviru postsocijalističkih zemalja- Poljske, Slovenije, Slovačke, Češke i Hrvatske. Utvrdili smo nekoliko općih karakteristika bitnih za razvoj socijalnih poduzeća za radnu integraciju. Sve analizirane države razvile su neki oblik financiranja socijalnih poduzeća za radnu integraciju, te sve imaju određeni zakonodavno- institucionalni oblik putem kojeg osiguravaju njegov razvoj. Većina ih je donijela barem jedan nacionalni dokument (akcijski plan ili nacionalnu strategiju) kojim dodatno potiču razvoj socijalnih poduzeća za radnu integraciju. Analizom smo utvrdili da socijalna poduzeća za radnu integraciju u postsocijalističkim europskim državama karakterizira zakašnjeli razvoj. Kao najčešće nedostatke razvoja socijalnog poduzetništva za radnu integraciju u analiziranim zemljama utvrdili smo: a) nepostojanje adekvatnog izvora financiranja socijalnih poduzeća za radnu integraciju; b) nedovoljnu razinu stručnosti i kompetencija djelatnika u tim poduzećima; c) nedovoljnu osviještenost javnosti o važnosti i vrednotama socijalnih poduzeća za radnu integraciju i njihova potencijala za uspješniju integraciju osoba s invaliditetom na tržište rada i u društvo.

Hrvatsku karakterizira značajno kasniji razvoj socijalnog poduzetništva naspram ostalih analiziranih zemlja, s malim udjelom socijalnih poduzeća za radnu integraciju. Neke od mogućih preporuka za hrvatski kontekst s obzirom na iskustva analize drugih zemalja mogu se odnositi na povećanje iznosa sredstava za zapošljavanje osoba s invaliditetom te kreiranje poticajnog okruženja za razvoj socijalnog poduzetništva, kroz informiranje i senzibilizaciju šire javnosti. Osim pitanja prepoznatljivosti socijalnog poduzetništva općenito, prepreka je svakako i manjak podrške političkih struktura, kao i nedostatak vještina za pokretanje ovog tipa socijalnog poduzetništva. Stoga je potrebno poticati edukaciju kroz formalno obrazovanje putem uvođenja obveznih kolegija o socijalnom poduzetništvu u relevantnim programima obrazovanja na hrvatskim sveučilištima i visokim školama, te također kroz unaprjeđenje segmenata neformalnog obrazovanja.

Određeni pomaci u praćenju podataka očekuju se uvođenjem registra socijalnih poduzeća, koje je planirano novom Strategijom. Potrebna je veća prepoznatljivost $u$ javnosti i njena senzibilizacija, koje bi se mogle ostvariti kampanjama o ulozi i vrednotama socijalnog poduzetništva i socijalnih poduzeća za radnu integraciju. Time bi socijalna poduzeća za radnu integraciju širila krug svojih korisnika, čime bi pospješila prodaju svojih proizvoda i usluga te unaprijedila vlastitu održivost na tržištu. Veća osviještenost osoba s invaliditetom o postojanju socijalnih poduzeća za radnu integraciju u zajednici doprinijela bi njihovoj motivaciji za uključivanje $u$ rad ovih poduzeća. U tome, kao i drugim aspektima 
razvoja socijalnih poduzeća za radnu integraciju, na raspolaganju stoje sredstva EU fondova. Kao i druga socijalna poduzeća, socijalna poduzeća za radnu integraciju susreću se s izazovima održivog financiranja, načina suočavanja s izazovima i regulatornim ograničenjima (Spear i Bidet, 2003), u čemu vidimo velik potencijal Strategije za razvoj socijalnog poduzetništva, koja predviđa izdašna sredstva, a kao jedan od ciljeva ima i unapređenje zakonskog i poreznog okvira.

Ova analiza mogla bi poslužiti kao daljnji poticaj razvoju socijalnog poduzetništva za radnu integraciju u Hrvatskoj, uz stavljanje naglaska na mogućnost ostvarivanja veće radne i socijalne integracije osoba s invaliditetom u hrvatsko društvo, kojemu za sada manjka adekvatnih oblika praksi i socijalnih inovacija u ovom području. Diseminacija ovakvog oblika djelovanja, po uzoru na uspješne primjere drugih zemalja, bila bi socijalna inovacija u hrvatskom kontekstu koja bi proširila mogućnosti zapošljavanja te radne i socijalne integracije osoba $\mathrm{s}$ invaliditetom. 


\section{LITERATURA}

Adam, S., Amstutz, J., Avilés, G., Caimi, M., Crivelli, L., Ferrari, D., Pozzi, D., Schmitz, D., Wüthrich, B., Zöbeli, D. (2015): Social Enterprise in Switzerland: The Field of Work Integration. ICSEM Working Papers, No. 19. Liege: The International Comparative Social Enterprise Models (ICSEM) Project.

Andruszkiewicz, O., Caisl, J., Polackova, Z., Andrejkovic, M. (2014): A map of social enterprises and their ecosystems in Europe- Country Report: Slovakia. Brussels: European Union.

ANED (2008): Report on the social inclusion and social protection of disabled people in European countries. United Kingdom: Leeds University.

Austin, J., Stevenson, H., Wei-Skillern, J. (2006): Social and Commercial Entrepreneurship: Same, Different, or Both? Entrepreneurship Theory and Pracitice, 30, 1, 1-20.

Babić, Z., Leutar, Z. (2010): Položaj osoba s invaliditetom na tržištu rada Republike Hrvatske. Socijalna ekologija,19,2, 195-214.

Baturina, D. (2013): Konceptualiziranje socijalnog poduzetništva i izazovi razvoja područja. Ekonomska misao i praksa, 22,1, 123-142.

Baturina, D. (2016): Wind in a back" or "bite of more than we can chew". First strategy and institutional trajectories of development of social entrepreneurship in Croatia. Paper presented in: Solidarity in Transition? Researching Social Enterprise in PostCommunist Societies": An International Scientific Colloquium. 21-22., 04. 2016., Tirana, Albanija.

Bežovan, G., Zrinščak, S. (2007): Civilno društvo u Hrvatskoj. Zagreb: Hrvatsko sociološko društvo.

Bežovan, G. (2008): Civilno društvo i kombinirana socijalna politika. U: Puljiz, V. Bežovan, G., Matković, T., Šućur, Z., Zrinščak, S. (ur.) Socijalna politika Hrvatske. Zagreb: Pravni fakultet Sveučilišta u Zagrebu.

Birkhölzer, K., Göler von Ravensburg, N., Glänzel, G., Lautermann, C., Mildenberger, G. (2015): Social Enterprise in Germany: Understanding Concepts and Context. ICSEM Working Papers, No. 14. Liege: The International Comparative Social Enterprise Models (ICSEM) Project.

Boschee, J., McClurg, J. (2003): Toward a Better Understanding of Social Entrepreneurship: Some Important Distinctions. Social Enterprise Alliance. Posjećeno 03.10.2016 na: http://www.se-alliance.org/betterunderstanding. pdf

Caisl J., Francová P., Pajas. P.J., Deverová, L. (2014): A map of social enterprises and their eco-systems in EuropeCountry Report: Czech Republic. Brussels: European Union.

Ciepielewska-Kowalik, A., Pieliński, B., Starnawska, M. i Szymańska, A. (2015): Social Enterprise in Poland: Institutional and Historical Context. ICSEM Working Papers, No. 11. Liege: The International Comparative Social Enterprise Models (ICSEM) Project.

Council of the European Union. (2015): The promotion of the social economy as a key driver of economic and social development in Europe - Draft Council Conclusions. Posjećeno 14. 10. 2016. na http://data.consilium.europa.eu/ doc/document/ST-13766-2015-INIT/en/pdf

Davister, C., Defourny, J., Gregoire, O. (2004): WISE in the European Union: An overview of existing models, EMES Working Papers, No. 04. Belgija: Liege.

Defourny, J. (2001): From Third Sector to Social Enterprise. U: Borzaga, C. and Defourny, J. (ur.): The Emergence of Social Enterprise (str.1-28). London: Routledge

Defourny, J., Nyssens, M. (2008): Social enterprise in Europe: recent trends and developments. Social enterprise journal, 4, 3, 202-228.

Defourny, J., Nyssens, M. (2010): Conceptions of Social Enterprise and Social Entrepreneurship in Europe and the United States: Convergences and Divergences. Journal of Social Entrepreneurship, 1, 1, 32 -53. 
Defourny, J., Nyssens, M. (2012): The EMES Approach of Social Enterprise in a comparative perspective. Working Paper No.12/3. EMES International Research Network, Liege-Belgium. Posjećeno 09. 10. 2016. na http://www.emes.net/what-we-do/publications/working-papers/the-emes-approach-ofsocial-enterprise-in-a-comparative-perspective/

Desa, G. i Kotha, S. (2006): Ownership, Mission and Environment: An Exploratory Analysis into the Evolution of a Technology Social Venture. U: Mair, J., Robinson, J. i Hockerts, K. (ur.): Social Entrepreneurship. (str.155-179). New York: Palgrave Macmillan.

DIESIS (2009): A WISE way of working Work Integration Social Enterprises and their role in European Policies. Guidelines for European Policy Makers. European and International Research and Development Service for the Social Economy and Co-operatives (DIESIS). Posjećeno 12. 09. 2016. na http://www.diesis.coop/jfiles/files/ WISE_guidelines_en.pdf

Dohnalová, M., Guri, D., Hrabětová, J., Legnerová, K., Šlechtová, V. (2015): Social Enterprise in the Czech Republic ICSEM Working Papers, No. 24. Liege: The International Comparative Social Enterprise Models (ICSEM) Project.

European Commission (2010): Europe 2020 Flagship Initiative Innovation Union. Posjećeno 14. 10. 2016. na http:// ec.europa.eu/research/innovation-union/pdf/innovation-union-communication-brochure_en.pdf

European Commission (2011): Single Market Act: Twelve levers to boost growth and strengthen confidence »Working together to create new growth. Posjećeno 15. 10. 2016. na http://ec.europa.eu/internal_market/smact/ docs/20120206_new_growth_en.pdf

European Commission (2011): Social Business Initiative. Creating a favourable climate for social enterprises, key stakeholders in the social economy and innovation. Posjećeno 15. 10. 2016. na http://ec.europa.eu/internal_market/ social_business/docs/COM2011_682_en.pdf

European Commision. (2013): Social Economy and Social Entrepreneurship. Social Europe Guide, Vol.4. Euricse (European Research Institute on Cooperative and Social Enterprises). European Commission. Posjećeno 24. 09. 2016. na http://ec.europa.eu/social/main.jsp?catId=738\&langId=en\&pubId=7523

Fraisse, L., Gardin, L., Laville, J.-L., Petrella, F. and Richez-Battesti, N. (2016): Social Enterprise in France: At the Crossroads of the Social Economy, Solidarity Economy and Social Entrepreneurship? ICSEM Working Papers, No. 34. Liege: The International Comparative Social Enterprise Models (ICSEM) Project.

Fuchs, M (2014): Quota Systems for Disabled Persons: Parameters, Aspects, Effectivity. Vienna: European Centre for social Welfare policy and research.

Galera, G. (2016): Social Enterprise in CEE and SEE: Trends and Challenges. Rad prezentiran na konferenciji: Solidarity in Transition? Researching Social Enterprise in PostCommunist Societies": An International Scientific Colloquium. 21-22. 04. 2016., Tirana, Albanija.

Haugh, H. (2006): Social Enterprise: Beyond Economic Outcomes and Individual Returns. U: Mair, J., Robinson, J., Hockerts, K. (ur.): Social Entrepreneurship, (str.180-206). New York: Palgrave Macmillan.

Heckl E., Pecher, I., Altonen, S., Stenholm, P. (2007): Study on Practices and Policies in the Social Enterprise Sector in Europe. Final Report. Austrian Institute for SME Research \& TSE Entre, Turku School of Economics Finland. Commissioned by the European Commission, DG Enterprise and Industry.

Hockerts, K. (2006): Entrepreneurial Opportunity in Social Purpose Business Ventures. U: Mair, J., Robinson, J., Hockerts, K. (ur.): Social Entrepreneurship, (str.142-154). New York: Palgrave Macmillan.

Human Dynamics (2010): Poticanje intenzivnijeg uključivanja osoba s invaliditetom na tržište rada - studija. Zagreb: Konzorcij Human Dynamics.

Huybrechts, B., Defourny, J., Nyssens, M., Bauwens, T., Brolis, O., De Cuyper, P., Degavre, F., Hudon, M., Périlleux, A., Pongo, T., Rijpens, J.,Thys, S. (2016): Social Enterprise in Belgium: A Diversity of Roots, Models and Fields. ICSEM Working Papers, No. 27. Liege: The International Comparative Social Enterprise Models (ICSEM) Project. 
Hrvatski zavod za javno zdravstvo (2015): Izvješće o osobama s invaliditetom u Hrvatskoj - 2015. Zagreb: Hrvatski zavod za javno zdravstvo.

Hrvatski zavod za zapošljavanje (2015): Izvješće o aktivnostima hrvatskoga zavoda za zapošljavanje u području zapošljavanja osoba s invaliditetom u razdoblju od 01. siječnja do 31. prosinca 2014. godine.

Hrvatski zavod za zapošljavanje (2016): Izvješće o aktivnostima hrvatskoga zavoda za zapošljavanje u području zapošljavanja osoba s invaliditetom u razdoblju od 01. siječnja do 31. prosinca 2015. godine.

ICF (2014): A map of social enterprises and their eco-systems in Europe. London: ICF Consulting Services Limited.

iPRESENT (2015): Mapiranje novih obzora- izvještaj o stanju društvenog poduzetništva u Hrvatskoj 2015. Zagreb: Institut društvenih znanosti Ivo Pilar.

Kadunc M., Bohinc. R., Kovačič, B. (2014a): A map of social enterprises and their eco-systems in Europe- Country Report: Slovenia. Brussels: European Union.

Kadunc, M., Singer, S., Petričević, T. (2014b): A map of social enterprises and their eco-systems in Europe-Country Report: Croatia. Brussels: European Union.

Kerlin, J. A. (2006): Social Enterprise in the United States and Europe: Understanding and Learning from the Differences. Voluntas, 17, 247-263.

Kiš-Glavaš, L. (2002): Profesionalna rehabilitacija osoba s posebnim potrebama. Zbornik radova 1. međunarodnog stručnog simpozija-Aktualnosti i perspektive zapošljavanja osoba s invaliditetom.(str. 40-54), Znaor, M. (ur.), 2.12. 2002. Zagreb: Ustanova za rehabilitaciju hendikepiranih osoba profesionalnom rehabilitacijom i zapošljavanjem (URIHO).

Kiš-Glavaš, L. (2009): Spremnost osoba s intelektualnim teškoćama na zapošljavanje. Revija za socijalnu politiku, $16,3,299-309$.

Kiš-Glavaš, L., Sokač, K. (2006). Istraživanje stavova poslodavaca o zapošljavanju osoba s invaliditetom. Zbornik radova s međunarodnog znanstvenog i stručnog skupa Rehabilitacija - stanje i perspektive djece s teškoćama u razvoju i osoba s invaliditetom (str. 56-64), Rijeka: Centar za rehabilitaciju Rijeka.

Kiš Glavaš, L. Majsec Sobota, V., Sokač, K., Gavrilović, A., Sobota, I. (2008): Zapošljivost nezaposlenih osoba s invaliditetom. Posjećeno 29. 09. 2016. na http://www.undp.hr/upload/fie/204/102043/FILENAME/nezaposleni_ web.pdf

Leutar Z., Milić Babić M. (2008): Pravo na rad i osobe s invaliditetom u RH. Sociologija i prostor, 180,2,161-187.

Ministarstvo obitelji, branitelja i međugeneracijske solidarnosti. (MOBMS) (2009): Socijalni položaj osoba s invaliditetom u Hrvatskoj. Zagreb. (neobjavljeno izvješće).

Nicholls, Alex, (ur.). (2006): Social Entrepreneurship - New Models of Sustainable Social Change, Oxford: Oxford University Press.

Nyssens, M., Defourny,J. Gardin,L, Laville, J-L, (2012) : Work integration social enterprises and public policy: an analysis of the European situation. Liege: EMES.

Nyssens, M. (2014): European Work Integration Social Enterprises: Between Social Innovation and Isomorphism. U: Defourny,J. Hulgård, L., Pestoff, V. (ur.): Social Enterprise and the Third Sector: Changing European Landscapes in a Comparative Perspective. (str.211-229). Routledge: Londres.

O'Connor, E. i Meinhard, A. (2014): Work Integration Social Enterprises (WISEs) Their Potential Contribution to Labour Market (Re-) Integration of At Risk Populations. Ontario: Centre for Voluntary Sector Studies.

Paczynski, W., Pacut, A., Potkanska, D., Pazderski, F. (2014): A map of social enterprises and their eco-systems in Europe Country Report: Poland. Brussels: European Union.

Peredo, A.M., McLean., M. (2006): Social entrepreneurship: A critical review of the concept. Journal of World Business, 41, 56-65. 
Program poticaja pri zapošljavanju osoba s invaliditetom za 2015.-2016. godinu (2015): Zagreb: Zavod za vještačenje, profesionalnu rehabilitaciju i zapošljavanje osoba s invaliditetom.

Robinson, J. (2006): Navigating social and institutional barriers to markets: how social entrepreneurs identify and evaluate opportunities. U: Mair, J., Robinson, J. i Hockerts, K. (ur.): Social Entrepreneurship, (str.235-275). New York: Palgrave Macmillan.

Seelos, C., Ganly, K., Mair, J. (2006): Social Entrepreneurs Directly Contribute to Global Development Goals. U: Mair, J., Robinson, J. i Hockerts, K. (ur.): Social Entrepreneurship, (str.121-136). New York: Palgrave Macmillan.

Skočić Mihić, S. (2004): Teškoće pri zapošljavanju i radu osoba s invaliditetom percipirane od strane poslodavaca. Magistarski rad. Edukacijsko-rehabilitacijski fakultet Sveučilišta u Zagrebu.

Sokol, P. (2010): Analysis of experiences with the introduction of the social economy in Slovakia. Report. Praha: Nova Ekonomika.

Spear, R., Bidet, E. (2003): The role of social enterprise in European labour markets. Working Paper No. 03/10. EMES International Research Network. Available at: http://www.emes.net/uploads/media/ELEXIES_WP_0310_Transversal_ENG.pdf

Strečanský,B., Stoláriková. K. (2012). Country studies. Social economy and social enterprises in Slovakia. CIVIL SZEMLE 4., 87-100.

Vajda Halal, Ž, Romić,D., Kolar., J.(2014): Uloga hrvatskoga zavoda za zapošljavanje u socijalnoj integraciji osoba s invaliditetom. Pravni vjesnik, 30,2, 393-403.

Vidal, I. i Claver, N. (2004): Work integration social enterprises in Spain. EMES Working Papers, No. 04/05. Belgija: Liege.

Vidović, D. (2012): Socijalno poduzetništvo u Hrvatskoj. Doktorska disertacija. Zagreb: Filozofski fakultet, Sveučilište u Zagrebu.

Vidović D. (2013): Social entrepreneurship in Croatia: a framework for development. Euricse Working Paper, No. $61 / 13$.

Vidović, D., Baturina, D. (2016): Social Enterprise in Croatia: Charting New Territories. ICSEM Working Papers, No. 32. Liege: The International Comparative Social Enterprise Models (ICSEM) Project.

Vincetić, V., Babić, Z., Baturina, D. (2013): Definiranje područja i potencijal razvoja socijalnog poduzetništva Hrvatske. Ekonomski pregled, 64,3, 256-278.

Vlada RH (2007.a): Nacionalna strategija izjednačavanja mogućnosti za osobe s invaliditetom od 2007. do 2015. godine (2007). Zagreb: Vlada Republike Hrvatske.

Vlada RH (2007.b): Zajednički memorandum o socijalnom uključivanju. Zagreb: Vlada Republike Hrvatske.

Vlada RH (2015): Strategija razvoja društvenog poduzetništva u Republici Hrvatskoj za razdoblje od 2015. do 2020. godine. Zagreb: Vlada Republike Hrvatske.

Zakon o profesionalnoj rehabilitaciji i zapošljavanju osoba s invaliditetom: Narodne novine,br. 157/13, 152/14.

Zakon o socialnem podjetništvu (ZSocP): [11] (Ur. 1. RS, št. 20/11 in 90/14 - ZDU-1I)

Zakon o zadrugama; Narodne novine, br. 34/11, 125/13, 76/14. 


\title{
WORK INTEGRATION SOCIAL ENTERPRISES (WISE) IN POST-SOCIALIST COUNTRIES
}

\begin{abstract}
The welfare state takes a stand against the demands of modernization by seeking to care for society's most vulnerable groups. People with disabilities are in a particularly vulnerable position, facing numerous obstacles to the labor market. Social enterprises, especially work integration social enterprises (WISE), can provide an important access point for their integration. The present analysis of five post-socialist countries in the European Union-Poland, Slovenia, Slovakia, Czech Republic, and Croatia - identifies several general characteristics essential for WISE development, such as the existence of some form of financing as well as certain legislative and institutional frameworks that remain underdeveloped. Lack of awareness and promotion of WISES as well as a shortage of necessary skills have delayed WISE development in these countries, particularly in Croatia, where WISEs are few with small numbers of employees. This study provides recommendations for improving the situation of WISEs in Croatia in order to help them facilitate the employment and social inclusion of people with disabilities and other vulnerable groups.
\end{abstract}

Key words: social entrepreneurship, work integration social enterprises, people with disabilities, employment and social inclusion 